\title{
Pelagicola litoralis gen. nov., sp. nov., isolated from coastal water in Korea
}

\author{
Yoon-Gon Kim, Chung Yeon Hwang and Byung Cheol Cho
}

Correspondence

Byung Cheol Cho

bccho@snu.ac.kr
School of Earth and Environmental Sciences and Research Institute of Oceanography, Seoul National University, Kwanak-gu, Seoul 151-742, Republic of Korea
A Gram-negative, strictly aerobic, non-motile, club-shaped bacterial strain, designated CL-ES2 ${ }^{\top}$, was isolated from coastal water from the east coast of Korea. Phylogenetic analysis of 16S rRNA gene sequences revealed that strain $\mathrm{CL}^{-E S} 2^{\top}$ was related to the genera Phaeobacter (95.0$96.6 \%$ similarity to the type strains), Leisingera (96.1\%) and Marinovum (95.6\%) in the family Rhodobacteraceae. However, strain $\mathrm{CL}^{-E S} 2^{\top}$ did not form a robust clade with any species of the Roseobacter clade, instead forming a distinct subline. The optimum temperature and $\mathrm{pH}$ for growth were $25{ }^{\circ} \mathrm{C}$ and $\mathrm{pH}$ 7. Strain $\mathrm{CL}-\mathrm{ES} 2^{\top}$ was able to grow with sea salts at concentrations in the range $2-6 \%$, with optimum growth occurring at 3-4\%. The major fatty acid was $\mathrm{C}_{18: 1} \omega 7 \mathrm{c}$ (75.2\%). The polar lipids were phosphatidylcholine, phosphatidylglycerol, phosphatidylethanolamine, an unidentified aminolipid and three unidentified lipids. The isoprenoid quinone was Q-10. The $\mathrm{G}+\mathrm{C}$ content of the DNA was $47.0 \mathrm{~mol} \%$. On the basis of the data from the polyphasic analysis, strain $\mathrm{CL}-\mathrm{ES} 2^{\top}$ represents a novel genus and species, for which the name Pelagicola litoralis gen. nov., sp. nov. is proposed. The type strain of Pelagicola litoralis is $\mathrm{CL}-\mathrm{ES} 2^{\top}(=\mathrm{KCCM}$ $42274^{\top}=$ DSM $18290^{\top}$ ).
The Roseobacter clade (family Rhodobacteraceae) is a major group in the class Alphaproteobacteria (Garrity et al., 2005). Currently, the Roseobacter clade comprises at least 38 genera (List of Prokaryotic Names with Standing in Nomenclature; http://www.bacterio.cict.fr/). The members of the Roseobacter clade are physiologically diverse, including micro-organisms demonstrating aerobic anoxygenic phototrophy, aerobic sulfite oxidation, methylotrophy, organic sulfur compound degradation and antibiotic production (Buchan et al., 2005; Martens et al., 2006). In this study, a bacterium, designated strain $\mathrm{CL}-\mathrm{ES} 2^{\mathrm{T}}$, was isolated from coastal water from the east coast of Korea, subjected to a polyphasic analysis and identified as representing a novel genus and species within the family Rhodobacteraceae.

Strain CL-ES2 ${ }^{\mathrm{T}}$ was isolated from coastal water from the east coast of Korea, using a standard dilution plating method on 100-fold-diluted R2A seawater agar medium (Lanoil et al., 2000); the plate was incubated at $25{ }^{\circ} \mathrm{C}$ for 15 days. The strain was able to grow on marine agar 2216 (MA; Difco) and was subsequently purified four times on

The GenBank/EMBL/DDBJ accession number for the 16S rRNA gene sequence of strain $\mathrm{CL}-\mathrm{ES} 2^{\top}$ is EF192392.

An extended neighbour-joining phylogenetic tree, a TLC of the polar lipids, micrographs of DAPI-stained cells and details of the whole-cell fatty acid composition of strain CL-ES2 ${ }^{\top}$ and related strains are available as supplementary material with the online version of this paper.
MA at $25{ }^{\circ} \mathrm{C}$. The strain was maintained both on MA at $4{ }^{\circ} \mathrm{C}$ and in marine broth 2216 (Difco) supplemented with $30 \%(\mathrm{v} / \mathrm{v})$ glycerol at $-80{ }^{\circ} \mathrm{C}$. Strain CL-ES2 ${ }^{\mathrm{T}}$ normally grows well on MA; however, an unexpected loss of viability occurred during our study. Notably, the viability seemed to be recoverable on MA supplemented with glucose $(0.5 \%$, $\mathrm{w} / \mathrm{v})$, after which the strain could be subsequently cultivated on MA.

For PCR amplification of the 16S rRNA gene, DNA was extracted from a single colony by using a boiling method (Englen \& Kelley, 2000). The crude extracts served as the DNA template for the PCRs, which involved Taq DNA polymerase (Bioneer) and primers $27 \mathrm{~F}$ and $1492 \mathrm{R}$ (Lane, 1991). The PCR product was purified using the AccuPrep PCR Purification kit (Bioneer). Direct sequence determination of the 16S rRNA gene was performed with an Applied Biosystems automated sequencer (ABI3730XL) at Macrogen Corp. (Seoul, Republic of Korea). The almostcomplete 16S rRNA gene sequence of the strain (1382 bp) was obtained and compared with 16S rRNA gene sequences available in the GenBank database by using BLASTN searches (Altschul et al., 1990). The 16S rRNA gene sequence was manually aligned with those of members of the family Rhodobacteraceae using the jPHYDIT program (Jeon et al., 2005). Phylogenetic trees were obtained by using the neighbour-joining (Saitou \& Nei, 1987), maximumparsimony (Fitch, 1971) and maximum-likelihood (Felsenstein, 1981) methods. An evolutionary distance 
matrix for the neighbour-joining method was generated according to the model of Jukes \& Cantor (1969). The robustness of tree topologies was assessed by means of bootstrap analyses based on 1000 replications (neighbourjoining and maximum-parsimony methods) or 100 replications (maximum-likelihood method). Phylogenetic analyses were carried out using MEGA3 (Kumar et al., 2004) and PAUP 4.0 (Swofford, 1998). Likelihood parameters were estimated using the hierarchical ratio tests in MODELTEST 3.04 (Posada \& Crandall, 1998). The DNA G + C content was determined using HPLC analysis (Tamaoka \& Komagata, 1984) at the Korean Culture Center of Microorganisms (Seoul, Republic of Korea).

For phenotypic and chemotaxonomic analyses, strain CL-ES2 ${ }^{\mathrm{T}}$ was routinely cultivated on MA. Gram staining was performed as described by Smibert \& Krieg (1994). The motility of the cells was determined using the hangingdrop method (Suzuki et al., 2001). Cell morphology was examined using phase-contrast microscopy (BX50; Olympus), epifluorescence microscopy (BX50; Olympus) and transmission electron microscopy (EX2; JEOL) with cells in the exponential phase (i.e. at 5-7 days) and stationary phase (i.e. at approx. 1 month) at $25{ }^{\circ} \mathrm{C}$ on MA. Anaerobic growth was assessed on MA and ZOF medium (Lemos et al., 1985) with additional agar content $(1.5 \%)$ by using the GasPak anaerobic system (BBL) at $25{ }^{\circ} \mathrm{C}$ for $21-40$ days. Accumulation of poly- $\beta$-hydroxybutyrate granules was determined by using Nile blue A staining (Ostle \& Holt, 1982). Catalase and oxidase activities were determined according to the protocols described by Smibert \& Krieg (1994). Bacteriochlorophyll $a$ production was determined spectrophotometrically in $90 \%$ acetone extracts from cells cultured either in the dark or in the light. Hydrolysis of hypoxanthine, starch, Tween 80 and xanthine was determined according to the protocols described by Hansen \& Sørheim (1991). In addition, arginine dihydrolase, aesculin hydrolysis, $\beta$ galactosidase, gelatinase, indole production, nitrate reduction and urease were tested using the API 20NE kit (bioMérieux) according to the manufacturer's instructions, except that the cell suspension was prepared using artificial seawater $\left(24 \mathrm{~g} \mathrm{NaCl}, 10.88 \mathrm{~g} \mathrm{MgCl}_{2} .6 \mathrm{H}_{2} \mathrm{O}, 4 \mathrm{~g} \mathrm{Na}_{2} \mathrm{SO}_{4}\right.$, $1.46 \mathrm{~g} \mathrm{CaCl}_{2} .2 \mathrm{H}_{2} \mathrm{O}, 0.7 \mathrm{~g} \mathrm{KCl}, 0.2 \mathrm{~g} \mathrm{NaHCO}_{3}, 0.1 \mathrm{~g} \mathrm{KBr}$, $0.027 \mathrm{~g} \mathrm{H}_{3} \mathrm{BO}_{3}, 0.04 \mathrm{~g} \mathrm{SrCl}_{2} .6 \mathrm{H}_{2} \mathrm{O}, 0.003 \mathrm{~g} \mathrm{NaF}, 1 \mathrm{l}$ distilled water; Lyman \& Fleming, 1940) as the suspension medium. The temperature range for growth was determined on the basis of colony formation on MA incubated at $5-45{ }^{\circ} \mathrm{C}$. The $\mathrm{pH}$ range $(\mathrm{pH} 4-12)$ for growth was determined from changes in the $\mathrm{OD}_{600}$ over time in marine broth 2216. Tolerance of sea salts was determined by assessing changes in the $\mathrm{OD}_{600}$ in synthetic ZoBell medium ( $5 \mathrm{~g}$ Bacto peptone, $1 \mathrm{~g}$ yeast extract, $0.1 \mathrm{~g}$ ferric citrate, 11 distilled water; Yi \& Chun, 2004) with different concentrations $(0-10 \%$ in increments of $1 \%$ and $15 \%$, w/v) of sea salts (Sigma) at $25{ }^{\circ} \mathrm{C}$. Carbon utilization was tested on basal agar medium supplemented with yeast extract $\left(23.6 \mathrm{~g} \mathrm{NaCl}, 0.64 \mathrm{~g} \mathrm{KCl}, 4.53 \mathrm{~g} \mathrm{MgCl}_{2} .6 \mathrm{H}_{2} \mathrm{O}\right.$,
$5.94 \mathrm{~g} \mathrm{MgSO}_{4} .7 \mathrm{H}_{2} \mathrm{O}, 1.3 \mathrm{~g} \mathrm{CaCl}_{2} \cdot 2 \mathrm{H}_{2} \mathrm{O}, 0.2 \mathrm{~g} \mathrm{NaNO}_{3}$, $0.2 \mathrm{~g} \mathrm{NH}_{4} \mathrm{Cl}, 15 \mathrm{~g}$ Bacto agar, $0.05 \mathrm{~g}$ yeast extract, $1 \mathrm{l}$ distilled water; Choi \& Cho, 2006) containing $0.2 \%$ carbon source. Growth was scored as negative when growth was equal to, or less than, that in the negative control (lacking a carbon source) after 30 days incubation at $25{ }^{\circ} \mathrm{C}$. All of the experiments were performed under aerobic conditions.

Isoprenoid quinones were isolated according to Minnikin et al. (1984) and analysed using HPLC as described by Collins (1985). The fatty acid methyl esters in whole cells grown on MA at $25{ }^{\circ} \mathrm{C}$ for 5 days were analysed with gas chromatography, according to the instructions of the Microbial Identification System (MIDI), at the Korean Culture Center of Microorganisms. Polar lipids were extracted using the procedures described by Minnikin et al. (1984) and were identified with two-dimensional TLC followed by spraying with appropriate detection reagents (Komagata \& Suzuki, 1987).

On the basis of 16S rRNA gene sequence similarity, strain CL-ES2 ${ }^{\mathrm{T}}$ was found to be most closely related to the genera Phaeobacter (95.0-96.6\% similarity to the type strains), Leisingera (96.1\%) and Marinovum (95.6\%). However, a phylogenetic analysis of the $16 \mathrm{~S}$ rRNA gene sequence of CL-ES2 ${ }^{\mathrm{T}}$ showed that the strain did not form a robust clade with those related genera, but instead formed a distinct subline in the Roseobacter clade (Fig. 1 and Supplementary Fig. S1, available in IJSEM Online). The $\mathrm{G}+\mathrm{C}$ content of the DNA was $47.0 \mathrm{~mol} \%$. The major isoprenoid quinone in strain CL-ES2 ${ }^{\mathrm{T}}$ was Q-10. The major fatty acid was $\mathrm{C}_{18: 1} \omega 7 c$ (75.2\%; Supplementary Table S1, available in IJSEM Online). The polar lipids found in strain CL-ES2 ${ }^{\mathrm{T}}$ were phosphatidylcholine, phosphatidylglycerol, phosphatidylethanolamine, an unidentified aminolipid and three unidentified lipids (Supplementary Fig. S2). Other phenotypic and physiological characteristics of strain CL-ES2 ${ }^{\mathrm{T}}$ are given in the genus and species descriptions; micrographs of cells of strain CL-ES2 ${ }^{\mathrm{T}}$ following DAPI staining are shown in Supplementary Fig. S3.

In addition to the phylogenetic separation of strain CL-ES2 ${ }^{\mathrm{T}}$ from the related genera (i.e. Phaeobacter, Leisingera and Marinovum) in the Roseobacter clade (Fig. 1), some phenotypic and chemotaxonomic characteristics can serve to differentiate the strain from these genera; there was a considerable difference between the DNA G+C content of strain CL-ES2 ${ }^{\mathrm{T}}(47.0 \mathrm{~mol} \%)$ and those of the related genera (55.7-64.9 mol\%; Table 1). The absence of an unidentified phospholipid, the absence of motility and the presence of Tween 80 hydrolysis in strain CL-ES2 ${ }^{\mathrm{T}}$ clearly distinguished the strain from the related genera Phaeobacter, Leisingera and Marinovum (Table 1). Strain CL-ES2 ${ }^{\mathrm{T}}$ can be differentiated from the genus Phaeobacter using other phenotypic traits, including amylase activity and the utilization of certain carbon sources (glycerol, leucine and succinate; Table 1). Strain CL-ES2 ${ }^{\mathrm{T}}$ can be distinguished from the genus Leisingera by the presence of 


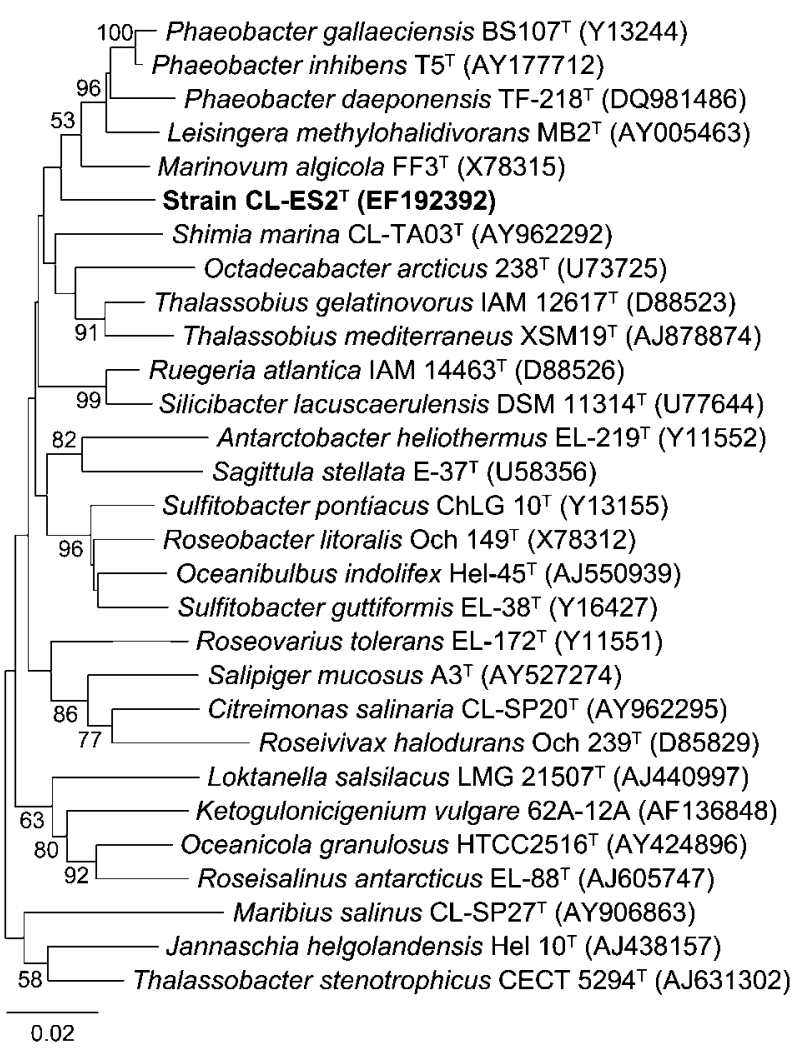

Fig. 1. Neighbour-joining phylogenetic tree, based on $16 \mathrm{~S}$ rRNA gene sequences, showing the position of strain $\mathrm{CL}^{-E S} 2^{\top}$ with respect to related taxa. Bootstrap percentages (based on 1000 resamplings) $>50 \%$ are shown at branching points. Alteromonas marina SW-47 ${ }^{\top}$ (GenBank accession no. AF529060) was used as an outgroup (not shown). Bar, 0.02 nucleotide substitutions per site. An extended version of this tree is available as Supplementary Fig. S1.

phosphatidylcholine and the utilization of certain carbon sources (acetate, dimethyl sulfate, glucose and serine; Table1). Furthermore, strain CL-ES2 ${ }^{\mathrm{T}}$ can be differentiated from the genus Marinovum on the basis of gelatinase activity and the utilization of certain carbon sources (citrate, serine, sucrose and trehalose; Table 1). In conclusion, phylogenetic analyses based on 16S rRNA gene sequences, DNA G $+\mathrm{C}$ contents, phenotypic features and the components of polar lipids suggest that strain CL-ES2 ${ }^{\mathrm{T}}$ represents a novel genus and species, for which the name Pelagicola litoralis gen. nov., sp. nov. is proposed.

\section{Description of Pelagicola gen. nov.}

Pelagicola [Pe.la.gi.co'la. L. n. pelagus the sea; L. suff. -cola (from L. n. incola) inhabitant; N.L. masc. n. Pelagicola inhabitant of the sea].

Cells are Gram-negative, non-motile, strictly aerobic, clubshaped rods. Not able to accumulate poly- $\beta$-hydroxybutyrate granules. Catalase- and oxidase-positive. Cells do not
Table 1. Differential phenotypic characteristics of strain CL-ES2 ${ }^{\top}$ and members of the genera Phaeobacter, Leisingera and Marinovum

Taxa: 1, strain CL-ES2 ${ }^{\mathrm{T}}$; 2, Phaeobacter inhibens (data from Martens et al., 2006); 3, Phaeobacter gallaeciensis (data from Ruiz-Ponte et al., 1998 unless indicated); 4, Phaeobacter daeponensis (Yoon et al., 2007); 5, Leisingera methylohalidivorans (Schaefer et al., 2002); 6, Marinovum algicola (Lafay et al., 1995). All of these organisms are positive for catalase and oxidase and contain phosphatidylglycerol, phosphatidylethanolamine, an unidentified aminolipid and unidentified lipids. All organisms are negative for Gram staining and bacteriochlorophyll $a$. +, Positive; -, negative; $\mathrm{W}$, weakly positive; $\mathrm{v}$, variable; ND, no data available.

\begin{tabular}{|c|c|c|c|c|c|c|}
\hline Characteristic & 1 & 2 & 3 & 4 & 5 & 6 \\
\hline Motility & - & + & + & + & + & + \\
\hline pH optimum & 7.0 & 7.5 & 7.0 & $7.0-8.0$ & 7.7 & 7.5 \\
\hline \multicolumn{7}{|l|}{ Growth at: } \\
\hline $4{ }^{\circ} \mathrm{C}$ & - & + & - & + & $+{ }^{a_{\star}}$ & - \\
\hline $37^{\circ} \mathrm{C}$ & - & - & + & + & $-{ }^{a}$ & + \\
\hline Nitrate reduction & - & - & - & + & - & - \\
\hline \multicolumn{7}{|l|}{ Hydrolysis of: } \\
\hline Gelatin & - & - & - & - & $-{ }^{a}$ & + \\
\hline Starch & + & - & - & - & + & + \\
\hline Tween 80 & + & - & - & - & $-^{a}$ & - \\
\hline \multicolumn{7}{|l|}{ Utilization of: } \\
\hline Acetate & + & + & $\mathrm{V}$ & + & - & $\mathrm{V}$ \\
\hline Arabinose & - & - & - & - & $-{ }^{a}$ & $-1+{ }^{b}$ \\
\hline Betaine & + & + & - & ND & + & ND \\
\hline Cellobiose & - & + & + & - & $-^{a}$ & $-1+{ }^{b}$ \\
\hline Citrate & - & + & - & + & - & + \\
\hline Dimethyl sulfate & - & - & $-^{a}$ & $\mathrm{ND}$ & + & ND \\
\hline Glucose & $\mathrm{w}$ & + & + & + & - & + \\
\hline Glycerol & - & + & + & + & - & - \\
\hline Leucine & - & + & + & + & $-{ }^{a}$ & $-{ }^{b}$ \\
\hline Rhamnose & - & - & - & ND & $-{ }^{a}$ & $-1+{ }^{b}$ \\
\hline Serine & + & + & - & + & - & $-{ }^{b}$ \\
\hline Succinate & - & + & + & + & $-^{a}$ & - \\
\hline Sucrose & - & + & + & - & $-{ }^{c}$ & $+{ }^{d}$ \\
\hline Trehalose & - & + & + & - & $-{ }^{a}$ & + \\
\hline Tween 80 & + & - & $-^{a}$ & $\mathrm{ND}$ & $-^{a}$ & $-{ }^{b}$ \\
\hline \multicolumn{7}{|l|}{ Polar lipids } \\
\hline Phosphatidylcholine & + & + & $+^{a}$ & + & $-^{a}$ & $+^{a}$ \\
\hline $\begin{array}{l}\text { Unidentified } \\
\text { phospholipid }\end{array}$ & - & + & $+^{a}$ & + & $+^{a}$ & $+^{a}$ \\
\hline $\begin{array}{l}\text { DNA G + C content } \\
(\mathrm{mol} \%)\end{array}$ & 47.0 & 55.7 & $57.6-58.0$ & 64.9 & 60.5 & $60.0^{d}$ \\
\hline
\end{tabular}

${ }^{\star}$ Data taken from the following studies: $a$, Martens et al. (2006); $b$, Labrenz et al. (1999); c, Yoon et al. (2007); d, Ruiz-Ponte et al. (1998).

contain bacteriochlorophyll $a$. The predominant isoprenoid quinone is Q-10. The predominant fatty acid is $\mathrm{C}_{18: 1} \omega 7 c$. The DNA $\mathrm{G}+\mathrm{C}$ content of the type strain of the type species is $47.0 \mathrm{~mol} \%$. The cellular polar lipids are phosphatidylcholine, phosphatidylglycerol, phosphatidylethanolamine, an unidentified aminolipid and three unidentified lipids. The type species is Pelagicola litoralis. 


\section{Description of Pelagicola litoralis sp. nov.}

Pelagicola litoralis (li.to.ra'lis. L. masc. adj. litoralis of the shore).

Exhibits the following properties in addition to those given in the genus description. After 10 days on MA medium at $25{ }^{\circ} \mathrm{C}$, colonies are circular, convex, creamy and approximately $0.7 \mathrm{~mm}$ in diameter. Cells appear singly, in pairs or in groups of three and are approximately $0.5-1.4 \mu \mathrm{m}$ wide and 1.1-7.0 $\mu \mathrm{m}$ long during the exponential growth phase. In old cultures (approx. 1 month), cells are cocci (1.0 $1.4 \mu \mathrm{m}$ in diameter) or short rods $(0.5-0.9 \mu \mathrm{m}$ wide and $1.2-1.8 \mu \mathrm{m}$ long). The optimum sea salts concentration for growth is $3-4 \%(\mathrm{w} / \mathrm{v})$, with a range of $2-6 \%$ (at $\mathrm{pH} 7)$. Growth is observed at $20-30{ }^{\circ} \mathrm{C}$ (optimum, $25{ }^{\circ} \mathrm{C}$ ) and at pH 6-8 (optimum, pH 7). Positive for hydrolysis of starch and Tween 80. Negative for hydrolysis of hypoxanthine and xanthine. With the API 20NE system, hydrolysis of aesculin and $\beta$-galactosidase (PNPG) activity occur, but arginine dihydrolase, hydrolysis of gelatin, indole production, nitrate reductase and urease are absent. Acetate, betaine, glucose, L-lysine, peptone, L-proline, serine and Tween 80 are utilized as sole carbon sources, but $\mathrm{N}$-acetylD-glucosamine, arabinose, ascorbate, cellobiose, citrate, DLcysteine, dimethyl sulfate, glycerol, glycogen, leucine, pyruvic acid, rhamnose, succinate, sucrose and trehalose are not utilized.

The type strain, CL-ES2 ${ }^{\mathrm{T}}\left(=\mathrm{KCCM} 42274^{\mathrm{T}}=\mathrm{DSM}\right.$ $\left.18290^{\mathrm{T}}\right)$, was isolated from coastal water from the east coast of Korea.

\section{Acknowledgements}

We acknowledge the expert technical support of Ms In-Sung Lee (electron microscopy) of the National Center for Inter-university Research Facilities at Seoul National University. This work was supported, in part, by the BK21 project of the Korean Government and the Ministry of Maritime Affairs and Fisheries (Sustainable Research and Development of the Dokdo; PM46400).

\section{References}

Altschul, S. F., Gish, W., Miller, W., Myers, E. W. \& Lipman, D. J. (1990). Basic local alignment search tool. J Mol Biol 215, 403-410.

Buchan, A., González, J. M. \& Moran, M. A. (2005). Overview of the marine Roseobacter lineage. Appl Environ Microbiol 71, 5665-5677.

Choi, D. H. \& Cho, B. C. (2006). Citreimonas salinaria gen. nov., sp. nov., a member of the Roseobacter clade isolated from a solar saltern. Int J Syst Evol Microbiol 56, 2799-2803.

Collins, M. D. (1985). Analysis of isoprenoid quinones. Methods Microbiol 18, 329-366.

Englen, M. D. \& Kelley, L. C. (2000). A rapid DNA isolation procedure for the identification of Campylobacter jejuni by the polymerase chain reaction. Lett Appl Microbiol 31, 421-426.

Felsenstein, J. (1981). Evolutionary trees from DNA sequences: a maximum likelihood approach. J Mol Evol 17, 368-376.

Fitch, W. M. (1971). Toward defining the course of evolution: minimum change for a specific tree topology. Syst Zool 20, 406-416.
Garrity, G. M., Bell, J. A. \& Lilburn, T. (2005). Family I. Rhodobacteraceae fam. nov. In Bergey's Manual of Systematic Bacteriology, 2nd edn, vol. 2, part C, pp. 161-229. Edited by D. J. Brenner, N. R. Krieg, J. T. Staley \& G. M. Garrity. New York: Springer.

Hansen, G. H. \& Sørheim, R. (1991). Improved method for phenotypical characterization of marine bacteria. $J$ Microbiol Methods 13, 231-241.

Jeon, Y.-S., Chung, H., Park, S., Hur, I., Lee, J.-H. \& Chun, J. (2005). jPHYDIT: a JAVA-based integrated environment for molecular phylogeny of ribosomal RNA sequences. Bioinformatics 21, 3171-3173.

Jukes, T. H. \& Cantor, C. R. (1969). Evolution of protein molecules. In Mammalian Protein Metabolism, vol. 3, pp. 21-132. Edited by H. N. Munro. New York: Academic Press.

Komagata, K. \& Suzuki, K. (1987). Lipid and cell-wall analysis in bacterial systematics. Methods Microbiol 19, 161-207.

Kumar, S., Tamura, K. \& Nei, M. (2004). MEGA3: integrated software for molecular evolutionary genetics analysis and sequence alignment. Brief Bioinform 5, 150-163.

Labrenz, M., Collins, M. D., Lawson, P. A., Tindall, B. J., Schumann, P. \& Hirsch, P. (1999). Roseovarius tolerans gen. nov., sp. nov., a budding bacterium with variable bacteriochlorophyll $a$ production from hypersaline Ekho Lake. Int J Syst Bacteriol 49, 137-147.

Lafay, B., Ruimy, R., Rausch de Traubenberg, C., Breittmayer, V., Gauthier, M. J. \& Christen, R. (1995). Roseobacter algicola sp. nov., a new marine bacterium isolated from the phycosphere of the toxinproducing dinoflagellate Prorocentrum lima. Int J Syst Bacteriol 45, 290-296.

Lane, D. J. (1991). 16S/23S rRNA sequencing. In Nucleic Acid Techniques in Bacterial Systematics, pp. 115-175. Edited by E. Stackebrandt \& M. Goodfellow. Chichester: Wiley.

Lanoil, B. D., Carlson, C. A. \& Giovannoni, S. J. (2000). Bacterial chromosomal painting for in situ monitoring of cultured marine bacteria. Environ Microbiol 2, 654-665.

Lemos, M. L., Toranzo, A. E. \& Barja, J. L. (1985). Modified medium for the oxidation-fermentation test in the identification of marine bacteria. Appl Environ Microbiol 49, 1541-1543.

Lyman, J. \& Fleming, R. H. (1940). Composition of sea water. J Mar Res 3, 134-146.

Martens, T., Heidorn, T., Pukall, R., Simon, M., Tindall, B. J. \& Brinkhoff, T. (2006). Reclassification of Roseobacter gallaeciensis RuizPonte et al. 1998 as Phaeobacter gallaeciensis gen. nov., comb. nov., description of Phaeobacter inhibens sp. nov., reclassification of Ruegeria algicola (Lafay et al. 1995) Uchino et al. 1998 as Marinovum algicola gen. nov., comb. nov., and emended descriptions of the genera Roseobacter, Ruegeria and Leisingera. Int J Syst Evol Microbiol 56, 1293-1304.

Minnikin, D. E., O’Donnell, A. G., Goodfellow, M., Alderson, G., Athalye, M., Schaal, A. \& Parlett, J. H. (1984). An integrated procedure for the extraction of bacterial isoprenoid quinones and polar lipids. J Microbiol Methods 2, 233-241.

Ostle, A. G. \& Holt, J. G. (1982). Nile blue A as a fluorescent stain for poly- $\beta$-hydroxybutyrate. Appl Environ Microbiol 44, 238-241.

Posada, D. \& Crandall, K. A. (1998). MODELTEST: testing the model of DNA substitution. Bioinformatics 14, 817-818.

Ruiz-Ponte, C., Cilia, V., Lambert, C. \& Nicolas, J. L. (1998). Roseobacter gallaeciensis sp. nov., a new marine bacterium isolated from rearings and collectors of the scallop Pecten maximus. Int J Syst Bacteriol 48, 537-542.

Saitou, N. \& Nei, M. (1987). The neighbor-joining method: a new method for reconstructing phylogenetic trees. Mol Biol Evol 4, 406425. 
Schaefer, J. K., Goodwin, K. D., McDonald, I. R., Murrell, J. C. \& Oremland, R. S. (2002). Leisingera methylohalidivorans gen. nov., sp. nov., a marine methylotroph that grows on methyl bromide. Int J Syst Evol Microbiol 52, 851-859.

Smibert, R. M. \& Krieg, N. R. (1994). Phenotypic characterization. In Methods for General and Molecular Bacteriology, pp. 607-654. Edited by P. Gerhardt, R. G. E. Murray, W. A. Wood \& N. R. Krieg. Washington, DC: American Society for Microbiology.

Suzuki, M., Nakagawa, Y., Harayama, S. \& Yamamoto, S. (2001). Phylogenetic analysis and taxonomic study of marine Cytophaga-like bacteria: proposal for Tenacibaculum gen. nov. with Tenacibaculum maritimum comb. nov. and Tenacibaculum ovolyticum comb. nov., and description of Tenacibaculum mesophilum sp. nov. and
Tenacibaculum amylolyticum sp. nov. Int J Syst Evol Microbiol 51, 1639-1652.

Swofford, D. L., (1998). PAUP: Phylogenetic analysis using parsimony, version 4. Sunderland, MA: Sinauer Associates.

Tamaoka, J. \& Komagata, K. (1984). Determination of DNA base composition by reversed-phase high-performance liquid chromatography. FEMS Microbiol Lett 25, 125-128.

Yi, H. \& Chun, J. (2004). Nocardioides ganghwensis sp. nov., isolated from tidal flat sediment. Int J Syst Evol Microbiol 54, 1295-1299.

Yoon, J.-H., Kang, S.-J., Lee, S.-Y. \& Oh, T.-K. (2007). Phaeobacter daeponensis sp. nov., isolated from a tidal flat of the Yellow Sea in Korea. Int J Syst Evol Microbiol 57, 856-861. 